\title{
Recent research on the evolution of land birds on the Galapagos
}

\author{
P. R. GRANT
}

Division of Biological Sciences, University of Michigan, Ann Arbor, Michigan 48109-1048, U.S.A.

A decade of research on the evolution of Galapagos land birds is reviewed. and outstanding questions to be answered are highlighted. Evolutionary studies have been restric 1 almost entirely to the four species of mockingbirds and the 13 species of Darwin's finches. Long-ierm field studies have been initiated on representatives of both groups. Co-operative breeding has been discovered in the mockingbirds (and hawks).

Lack's (1945, 1947) monographic treatment of Darwin's finches has been largely upheld and extended by morphological, ecological, behavioural and biochemical studies. While the phylogenetic origins of Darwin's finches still remain uncertain, the major groupings of the finches have been confirmed by the results of protein polymorphism analysis. Fossils of Darwin's finches have been discovered recently: their potential for illuminating evolutionary change has not yet been realized. Three other major developments are (1) quantitative confirmation of the role of interspecific competition in the adaptive radiation, (2) experimental confirmation of the role of morphological and song cues in species recognition, and experimental evidence of their evolution in the speciation process, and (3) direct study of natural selection on heritable quantitative traits in a population, and identification of its causes. Continuing studies of population variation are likely to reveal the contemporary importance of selection, migration and hybridization, and thereby help us to more fully understand the causes of the adaptive radiation of Darwin's finches.

KEY WORDS:-Darwin's finches - mockingbirds - speciation - competition - reproductive isolation - phylogeny - fossils - natural selection.

\section{CONTENTS}

Introduction

Mockingbirds .

Darwin's finches

What are their systematic origins?

How many species evolved, how many became extinct and over what period of time? 119

Why have no more species evolved? . . . . . . . . . . . . . . . 122

How is the adaptive radiation explained? . . . . . . . . . . . . . . 125

Some current and future developments . . . . . . . . . . . . . . . . 131

This is the house that Lack built

Acknowledgements

References.

\section{INTRODUCTION}

There are 28 species of land birds resident on the Galapagos: all but six are endemic (Table 1). Until recently most of our knowledge about them has come 
Table 1. The resident species of Galapagos land birds (Harris, 1973a; Grant, 1983a). *Indicates an endemic species. $G$. difficilis was originally named G. nebulosa (Sulloway, 1982a, 1982b)

\begin{tabular}{|c|c|}
\hline English name & Scientific name \\
\hline $\begin{array}{l}\text { Galapagos Hawk } \\
\text { Galapagos Rail } \\
\text { Paint-billed Crake } \\
\text { Galapagos Dove } \\
\text { Dark-billed Cuckoo } \\
\text { Barn Owl } \\
\text { Short-eared Owl }\end{array}$ & $\begin{array}{l}\text { * Buteo galapagoensis } \\
\text { *Laterallus spilonotus } \\
\text { Neocrex erythrops } \\
\text { * Zenaida galapagoensis } \\
\text { Coccyzus melacorhyphus } \\
\text { Tyto alba } \\
\text { Asio fammeus }\end{array}$ \\
\hline $\begin{array}{l}\text { Vermillion Flycatcher } \\
\text { Large-billed Flycatcher } \\
\text { Galapagos Martin }\end{array}$ & $\begin{array}{l}\text { Pyrocephalus rubinus } \\
\text { * Myiarchus magnirostris } \\
\text { * Progne modesta }\end{array}$ \\
\hline $\begin{array}{l}\text { Galapagos Mockingbird } \\
\text { Charles Mockingbird } \\
\text { Hood Mockingbird } \\
\text { Chatham Mockingbird }\end{array}$ & $\begin{array}{l}\text { *Nesomimus parvulus } \\
\text { *Nesomimus trifasciatus } \\
\text { * Nesomimus macdonaldi } \\
\text { * Nesomimus melanotis }\end{array}$ \\
\hline $\begin{array}{l}\text { Yellow Warbler } \\
\text { Small Ground Finch } \\
\text { Medium Ground Finch } \\
\text { Large Ground Finch } \\
\text { Sharp-beaked Ground Finch } \\
\text { Cactus Ground Finch } \\
\text { Large Cactus Ground Finch } \\
\text { Vegetarian Finch } \\
\text { Small Tree Finch } \\
\text { Medium Tree Finch } \\
\text { Large Tree Finch } \\
\text { Woodpecker Finch } \\
\text { Mangrove Finch }\end{array}$ & $\begin{array}{l}\text { Dendroica petechia } \\
\text { *Geospiza fuliginosa } \\
\text { *Geospiza fortis } \\
\text { *Geospiza magnirostris } \\
\text { *Geospiza difficilis } \\
\text { *Geospiza scandens } \\
\text { *Geospiza conirostris } \\
\text { * Platyspiza crassirostris } \\
\text { *Camarhynchus parvulus } \\
\text { *Camarhynchus pauper } \\
\text { *Camarhynchus psittacula } \\
\text { *Cactospiza pallida } \\
\text { *Cactospiza heliobates }\end{array}$ \\
\hline Warbler Finch & ${ }^{*}$ Certhidea olivacea \\
\hline
\end{tabular}

from studies of museum specimens. Ten years ago it could be said that, in terms of breeding behaviour and population ecology, sea-birds on the Galapagos were known better than the land-birds. The situation is now reversed, as a result of extensive field studies of hawks, mockingbirds and Darwin's finches. Nevertheless it is still true that most of the species of land birds are poorly known.

In this article I shall review advances in our understanding of the evolution of mockingbirds and finches. Evolutionary studies of the other species have lagged behind. Although, in the last few years, we have learned more about the behaviour and ecology of the hawk (de Vries, 1975, 1976; Faaborg et al., 1980), rail (Franklin, Clark \& Clark, 1979), dove (Grant, P. R. \& Grant, K. T., 1979; Grant, P. R. \& Grant, B. R., 1980a) and short-eared owl (de Vries, 1975; Grant, P. R. et al., 1975; Grant, P. R. \& Grant, B. R., 1980a), the evolutionary forces on the Galapagos that have shaped their features of interest have not been the prime focus of studies. For example, it has been established that the hawk has a co-operative, polyandrous, breeding system (deVries, 1975, 1976). The incidence of polyandry varies among island populations. The study of such variation can lead to a better understanding of the maintenance of the co- 
operative breeding habit (Faaborg et al., 1980, Faaborg \& Patterson, 1981). But since the related continental species, Buteo harrisi, also exhibits this breeding system (Mader, 1979), it is unlikely to have evolved on the Galapagos. Therefore, I will omit it from the review, and concentrate instead on the broad questions of evolution on the Galapagos islands that have been illuminated by research conducted in the last ten years.

\section{MOCKINGBIRDS}

Mockingbirds pose some interesting evolutionary problems. They have differentiated into four forms recognizable by plumage patterns, size and eye colour. The pattern of differentiation is not understood, and we are not even certain that the four forms are different species as currently recognized (Harris, 1973, 1974). Bowman \& Carter (1971) kept $\mathcal{N}$ esomimus parvulus, $\mathcal{N}$. trifasciatus and $\mathcal{N}$. macdonaldi in captivity and reported without further detail that "all attempts to hybridize them failed". These negative results are at least consistent with the current practice of treating the forms as separate species.

Figure 1 shows their distribution in the archipelago. Each one of three species is restricted to one large southern island and its satellites: the fourth is widely distributed through the archipelago, but its populations are not strongly differentiated. No two species occur on the same island. They may be the product of one or more colonizations from the continent. Their distribution, like their differentiation, has yet to be explained satisfactorily (see Swarth, 1931).

Mockingbirds present a taxonomic puzzle too. Unless the ancestral species on the continent has become extinct, all island species are derived from the ancestors of the single species in western South America, Mimus longicaudatus. This species is distinctive in wing, tarsus and bill dimensions but not especially so in relation to variation among Galapagos species. For this reason Abbott \& Abbott (1978) place the island species in the same genus (Mimus) as the mainland species, just as Rothschild \& Hartert (1899) had done many years earlier. However the continental species is also distinctive in plumage, so whether one or two genera should be adopted, in recognition of the attainment of a particular level of evolutionary divergence in the archipelago, is a difficult question to resolve. Results of captive breeding could shed light on this question, but if anything they add confusion. Having failed to interbreed the island species, all unquestionably congeneric, Bowman \& Carter (1971) accidentally brought about a cross between a male $M$. longicaudatus and a female $\mathcal{N}$. parvulus! One of the progeny reached adulthood. The generic status of Galapagos mockingbirds is therefore uncertain.

Aside from classification problems, another evolutionary problem has come to light in the last few years. Like the hawks, Galapagos mockingbirds breed cooperatively (Grant, P. R. \& Grant, N., 1979). Unlike the hawks, the breeding system is monogamous, with young males, almost invariably sons, helping the parents to feed their nestlings. Kinnaird \& Grant (1982) reasoned that the cooperative breeding habit was possessed by mockingbirds at the time they colonized the Galapagos. This appears to be wrong. A detailed, unpublished, breeding study of $M$. longicaudatus in Peru (M. D. Williams, pers. comm.) produced no evidence of co-operative breeding. Therefore it seems likely that the habit evolved on the islands: if so, why? Why is it a regular feature of mockingbird breeding? In contrast, helping at the nest appears to be only an 


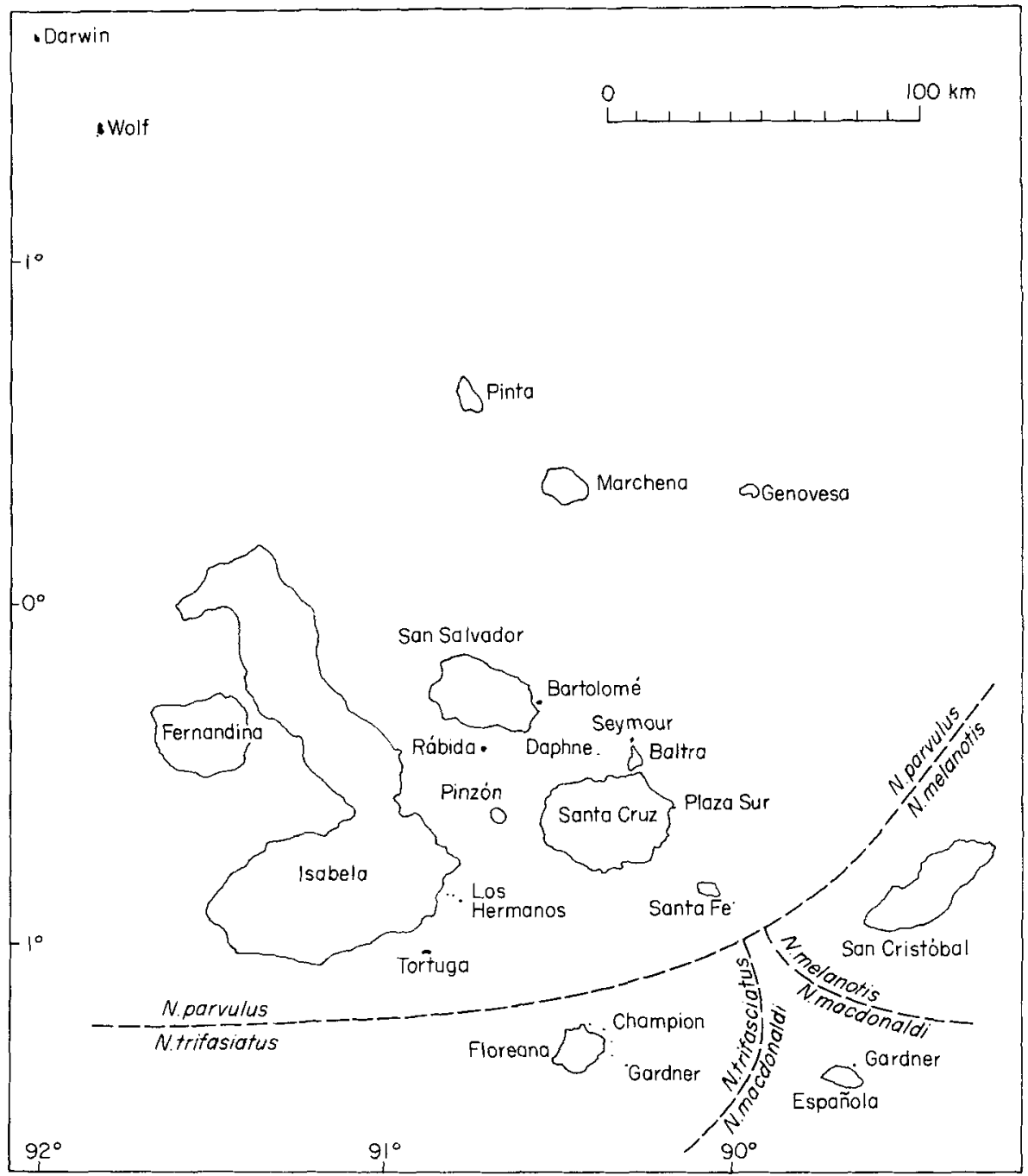

Figure 1. The distribution of four species of mockingbirds (Nesomimus spp.) in the Galapagos.

occasional and accidental feature of finch breeding (Price, Millington \& Grant, 1983).

Two approaches are being used to answer these questions (R. L. Curry, pers. comm.). One is to apply general models for the evolution of co-operative breeding in birds (Brown, 1974, 1978; Emlen, 1978, 1982a, 1982b) to Galapagos mockingbirds. The models are modified to allow for the ecological differences between continent and islands, such as the different risks of predation (Marchant, 1960; Grant, P. R. \& Grant, B. R., 1980a).

The second approach is to make a comparative study of the breeding structure of populations on different islands in order to identify the most influential factors and their effects. Breeding structure is certainly likely to vary among populations. For example, on the 10 ha island of Champion near I. Floreana there were only 49 mockingbirds ( $\mathcal{N}$. trifasciatus) in 1980 (unpubl. pers. 
obs.). This probably inbred population had a female-biased sex ratio. In the same year the population of at least $3000 \mathcal{N}$. parvulus on I. Genovesa had a male-biased sex ratio (Kinnaird \& Grant, 1982). In the five years this population has been studied, the maximum size of a group participating in territorial defence in the non-breeding season was nine individuals. In contrast, Hatch (1966) observed a group of up to 40 individuals in a single season's study of the population ( $\mathcal{N}$. macdonaldi) on I. Española. Studies of these populations by R. L. Curry and myself are continuing.

\section{DARWIN'S FINCHES}

Monographs by Lack (1945, 1947) and Bowman (1961) dealt comprehensively with the evolution of this group of birds. I shall summarize recent additions to our knowledge in answers to five major questions. Where did they come from? Which species gave rise to which? How many species evolved and over what period of time? Why have no more species evolved? Why did they evolve in the directions they did?

\section{What are their systematic origins?}

There is general agreement that the closest relatives are emberizine finches in South or Central America. There is also general agreement that they are all more closely related to each other than any one is to a living species on the continent. There is no agreement on the most closely related continental species. Bowman (1961) favoured a species, Melanospiza richardsoni, living not on the continent but on the West Indian island of St Lucia; see also Cutler (1970). Harris (1972) stressed the similarities between Darwin's Finches and Coereba faveola. Steadman (1982a) has made the most comprehensive attempt to come to grips with this problem and proposed that two races of Volatinia jacarina, one in Central America and the other in South America, provided two separate groups of colonists to Cocos Island and the Galapagos respectively, and from these all Darwin's finches are derived.

None of these attempts to answer the question lay all doubts to rest. Steadman (1982a) exposed and discussed weaknesses of preceding efforts to identify the continental descendant of the ancestral species. However his candidate, $V$. jacarina, differs conspicuously from all of Darwin's finches by a highly characteristic vertical display flight performed by males, and by an open cup-shaped nest-all Darwin's finches build domed nests. The climatic environments of $V$. jacarina and Darwin's finches on the Galapagos are not very different, therefore it is not clear why such marked behavioural differences would have evolved on the Galapagos if $V$. jacarina was close to the ancestral stock.

Thus the ancestors of Darwin's finches have not been unambiguously identified by studies of phenotypic resemblance. The solution to the problem may be reached by studies of genetic resemblance. Sibley \& Ahlquist (in press) and C. G. Sibley (pers. comm.) have used the technique of DNA-DNA hybridization to assess the systematic relationships of many species of passerine birds. Some of their findings are surprising. Many $\mathrm{S}$ American species currently classified as emberizine finches are in fact more closely related to members of the 
Thraupidae (tanagers) than to emberizines. Conceivably then, Darwin's finches are not finches, but like many finch-like species on the continent they are tanagers. If so they should be called Darwin's finch-tanagers. Extension of the DNA-DNA hybridization technique to Darwin's finch material holds the promise of a resolution of the problem of identifying the systematic origins of the group and the most closely-related, extant, continental species (C. G. Sibley, pers. comm.).

\section{What are their ancestor-descendant relationships?}

Lack (1947) used the similarities and differences among species in plumage, size and shape, especially of the bill, to construct a tentative phylogenetic tree (Fig. 2). The main features of the tree are (a) an early differentiation of warbler-like finches (Certhidea olivacea on the Galapagos and Pinaroloxias inornata on Cocos Island) from the ancestral stock, (b) subsequent separation of the tree finches from the remainder (ground finches), and (c) an even later differentiation of the tree finch and ground finch groups, with $G$. difficilis being closest to the ancestor.

The main features of this scheme have been confirmed by the results of an analysis of protein polymorphisms (Yang \& Patton, 1981; Polans, 1983; initiated by Ford, Ewing \& Parkin, 1974). First, the warbler finch is the most distinctive species (Fig. 3), biochemically, and hence diverged from the rest at the earliest time (Yang \& Patton, 1981). Second, the six ground finches cluster together, and four of the tree finches cluster together: material was lacking for the other two species. Barrowclough (1983) has integrated the results of the morphological and biochemical studies.

A small discrepancy with Lack's tree is that the tree finches are found to have differentiated more recently than the beginning of the ground finch differentiation (Yang \& Patton, 1981). Also by this analysis $G$. difficilis is not

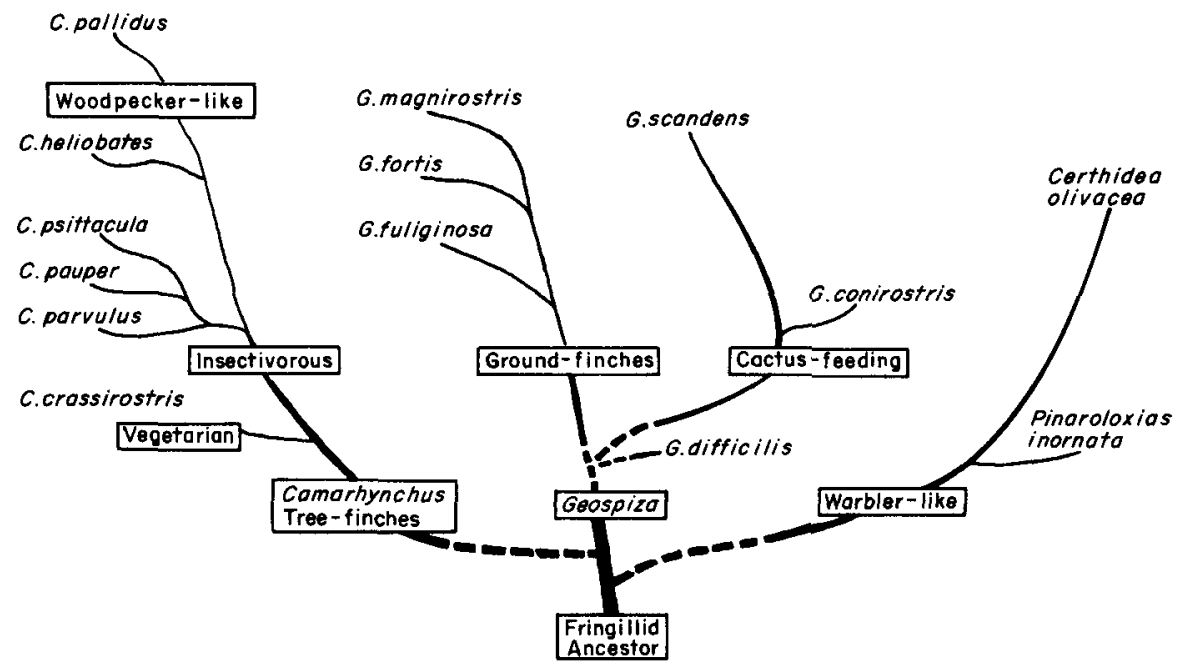

Figure 2. A tentative evolutionary tree of Darwin's finches suggested by Lack (1947). Pinaroloxias inornata occurs on Cocos Island, all other species occur on the Galapagos. 


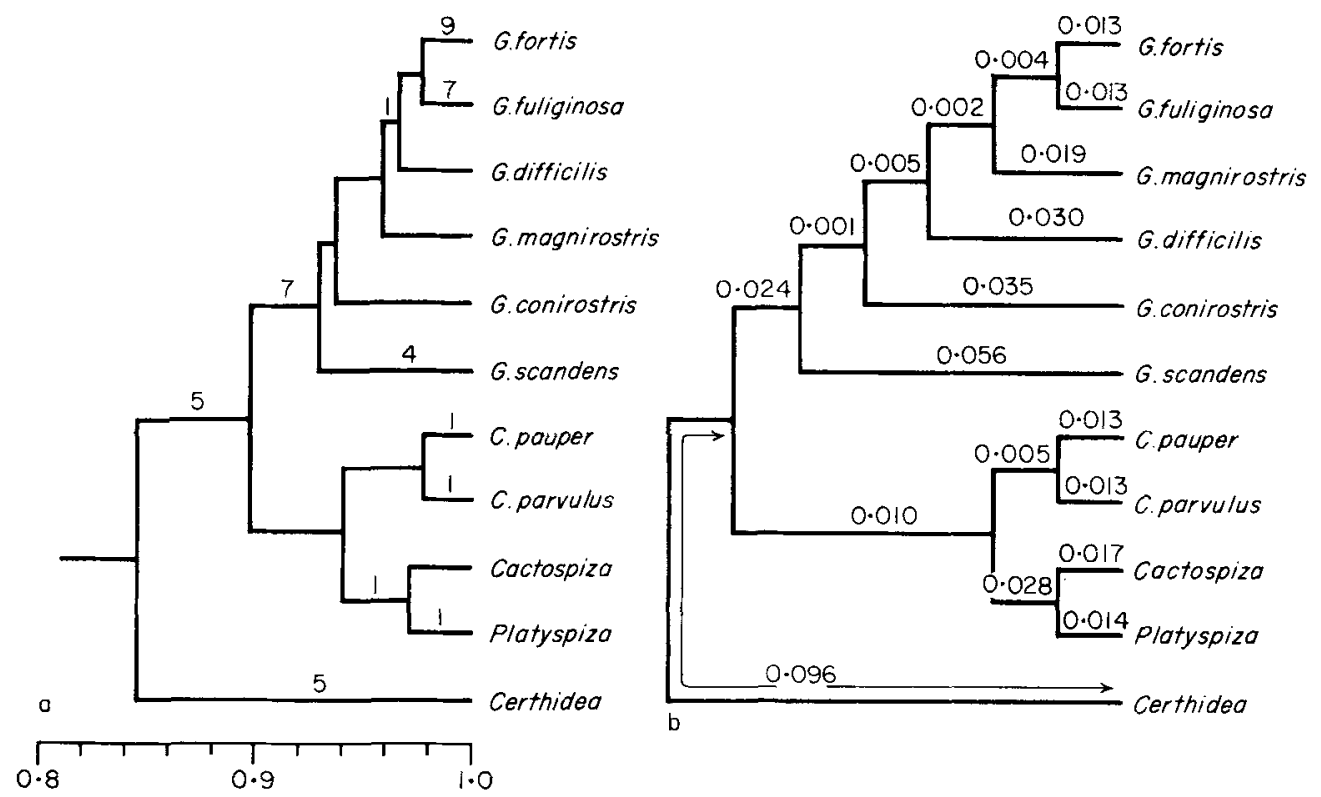

Figure 3. Relationships among Darwin's finch species based on an analysis of protein polymorphisms (from Yang \& Patton, 1981). Numbers along branch lengths of the dendrogram are Rogers' distance coefficients. G. = Geospiza, and $\mathrm{C}=$ Camarhynchus. Note the similarity of the clustering here and the grouping of species in Fig. 2, where Cactospiza pallidus and Platyspiza crassirostris were placed by Lack (1947) in the genus Camarhynchus.

revealed to be particularly distinctive within the ground finch group; but ground finches are all so similar it is doubtful whether the exact sequence of differentiation of the six species can be reliably estimated by this technique at present. Nor can it be estimated by examination of chromosome structure and numbers, at least not with current techniques, because there is a large degree of variation within species in both chromosome features (Jo, 1983). Again, the DNA-DNA hybridization technique has the best potential of resolving these problems at the species level.

\section{How many species evolved, how many became extinct and over what period of time?}

Geological data suggest that the islands are no more than five million years old (Bailey, 1976; Hey, 1977; Cox, 1983). This sets the maximum span of time over which the full adaptive radiation of Darwin's Finches occurred. The biochemical differences between the species can be converted to times since their evolutionary separation by applying Nei's method of dating. This allows an estimation to be made of the actual time course of the radiation. Yang \& Patton (1981) provide these estimates, and discuss the uncertainties of the assumptions upon which the method rests (see also Thorpe, 1982). They calculate that Certhidea olivacea split off from the ancestral stock about 570000 years ago. This first differentiation may have occurred earlier, as early as $1.5-2.0$ million years ago, if more conservative assumptions about the equivalence of electrophoretic distance and time are correct (Yang \& Patton, 1981; see also Sarich, 1977; Thorpe, 1982). Nevertheless, the overall conclusion is that Darwin's finches 
have occupied the islands for a relatively short period of time, and have differentiated rapidly, for example in relation to the Hawaiian honeycreepers (estimated to be 15-20 million years by Sibley \& Ahlquist, 1982).

The temporal pattern of speciation is illustrated in Fig. 4. Figure 4A shows that the unstandardized rate of speciation increased to a maximum in the interval 50000-100000 years B.P. (before present), and that no further speciation occurred in the most recent interval. But Fig. 4A is based on extant forms only, and a true pattern of speciation can only be obtained by incorporating extinctions, if they have occurred. This point is illustrated in Fig. 4B: modern material is used to estimate the $C$ curve, but the total number of species evolved ( $T$ curve) could be seriously underestimated if extinctions have been numerous.

Fossils are required to provide estimates of the curves in Fig. 4B, and to identify our current position on the time axis. Fossils have seemed impossible to obtain from volcanic islands such as the Galapagos, but recently Steadman (1982b, pers. comm.) has assembled and identified a remarkable collection of bones from cracked lava tubes on Islas Floreana (Table 2) and Santa Cruz (pers. comm.). The dated fossils are no older than 2400 years B.P.: undated ones
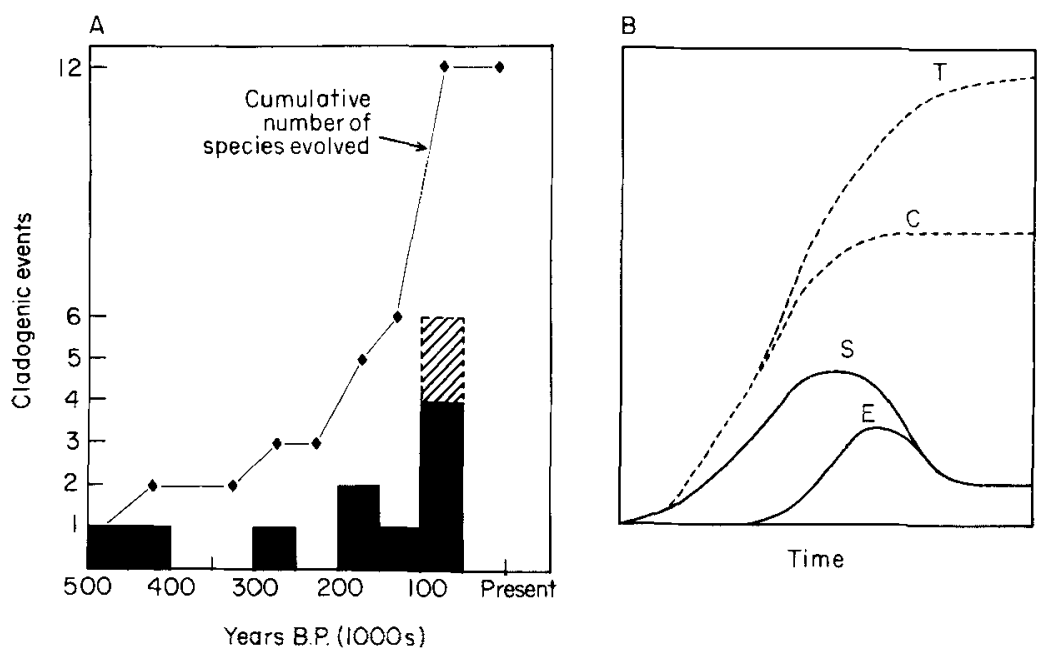

Figure 4 A, B. The temporal pattern of speciation of Darwin's finches. A, The number of speciation events occurring in each 50000 year period, based on data in Yang \& Patton (1981). The hachured part of the histogram refers to two species, Camarhynchus psittacula and Cactospiza heliobates, not studied by Yang \& Patton (1981): the time of their formation has been estimated on the basis of their morphological similarity with congeners of known times of origin. The accumulation of species is shown by a continuous line. Note the absence of recent speciation: if anything, the recent period without speciation has been underestimated (see Yang \& Patton, 198I), and perhaps the whole time span has been underestimated (see text). B, Hypothetical curves of speciation ( $S$ ) and extinction (E) and the accumulation of species in total $(\mathbf{T})$ and at any one time $(\mathbf{C})$. It is assumed that there is a fixed maximum number of species sustainable in the archipelago and that this maximum is approached in dampened fashion $(C)$ as a result of a rise and fall in the speciation rate (S) and, with a lag, a rise and fall in the extinction rate $(\mathrm{E})$. The difference between $T$ and $\mathrm{C}$ is solely attributable to $\mathrm{E}$. The $\mathrm{C}$ curve has approximately the same form as the cumulative species curve in the upper diagram: the difference is that the $\mathrm{C}$ curve is the product of speciation and extinction whereas the equivalent curve in the upper diagram is estimated from extant forms only. Rates of speciation and extinction represented by solid line, cumulative and total number of species shown by broken line. 
Table 2. Numbers of individual represented by fossils (from Steadman, 1982b, and pers. comm.) and by male specimens (skins) in Museum collections (from Lack, 1947). Geospiza negulosa, as used by Steadman (1982b), is synonymous with $G$. difficilis in Table 1

\begin{tabular}{lrr}
\hline & \multicolumn{2}{c}{ I. Floreana } \\
\cline { 2 - 3 } & Fossils & Skins \\
\hline Geospiza magnirostris & 229 & 5 \\
Geospiza fortis & 12 & 181 \\
Geospiza fuliginosa & 18 & 86 \\
Geospiza nebulosa & 6 & 4 \\
Geospiza scandens & 2 & 102 \\
Platyspiza crassirostris & 4 & 24 \\
Camarhynchus psittacula & 0 & 3 \\
Camarhynchus pauper & 3 & 80 \\
Camarhynchus parvulus & 1 & 86 \\
Certhidea olivacea & 7 & 25 \\
\hline
\end{tabular}

are probably much older. They are believed to be derived largely from disintegrated barn owl pellets (Steadman, 1982b).

Work currently in progress suggests the possibility that two Geospiza species have become extinct on I. Santa Cruz in the last 2400 years (D. W. Steadman, pers. comm.). The final taxonomic judgement as to whether some bones from I. Santa Cruz belong to extinct or extant species has not been rendered. If they belong to extinct species, they will provide the first evidence that Darwin's finches differentiated further than is shown by the 14 living species, and they will provide the first step in the construction of extinction and total species curves, illustrated in hypothetical form in Fig. 4B.

Fossils also have the potential of providing a documentation of evolutionary change. The fossils from I. Santa Cruz and I. Floreana have not yet been studied in sufficient detail for an analysis of evolution.

A third value of fossils is in providing estimates of changes in community membership through time. In Table 2 I have listed the minimum number of individuals represented by fossils on I. Floreana, without regard to time. For comparison I have also listed the number of specimens in museum collections from the same island as a measure of the current relative abundance of those species. The measure is only approximate, but it is correlated with the number of birds trapped in mist nets in a standard census period (Fig. 5). Two results of the comparison are worth mentioning. First, all species that are present on Floreana now, or were present when Darwin visited it, but subsequently became extinct, are represented in the fossil collections, with the trivial exception of Camarhynchus psittacula. The exception is not surprising because the species is rare, and occurs in the highlands, whereas the source of the fossils is in the lowlands. Second, there is a mismatch in relative abundances in fossil and modern collections. Not all differences can be attributed to collecting biases. Geospiza magnirostris dominates the fossil record, perhaps because the fossils were derived from owl pellets and perhaps because the barn owls preyed selectively on this finch species as its relative, the short-eared Owl, is known to do (Grant, P.R. \& Grant, B.R., 1980a). Geospiza magnirostris specimens are rare in modern collections 


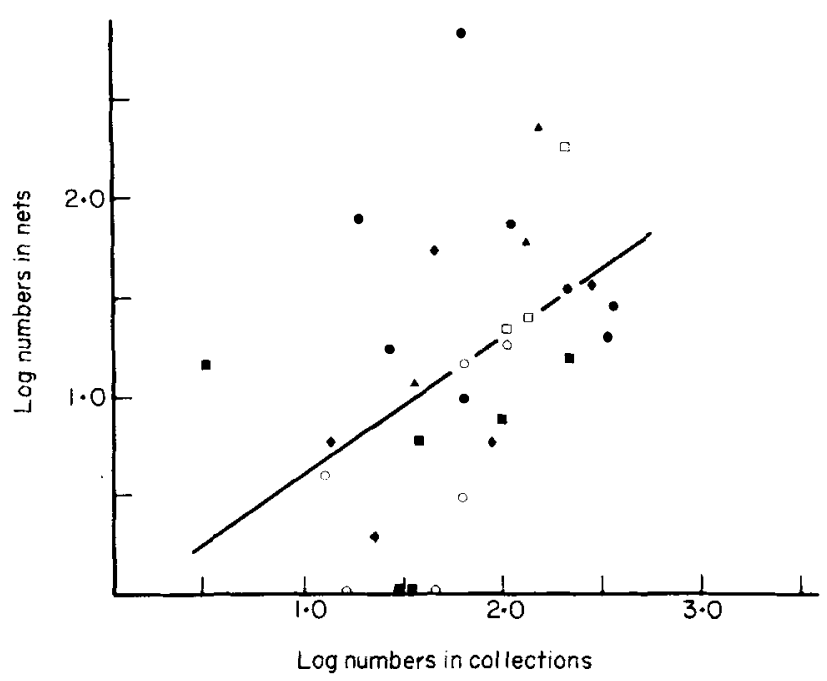

Figure 5. The relationship between numbers of specimens of Geospiza species from different islands in Museum collections and numbers of birds of the same species and from the same islands trapped in mist nets in a standard way in the dry season (data from Grant et al., 1975; Abbott et al., 1977; Smith et al., 1978; Schluter, 1982b; Schluter \& Grant 1982; and unpubl.). The correlation is statistically significant $(P<0.05)$. Islands include Santa Cruz but not Floreana (see Table 2). Symbols: G. fuliginosa, $\Delta$ G. difficilis, G. fortis, $\square$. scandens, $\square$ G. conirostris, $\bigcirc G$. magnirostris.

from I. Floreana because it went extinct after Darwin's visit, probably for reasons associated with human settlement of the island (Sulloway, 1982a, $1982 \mathrm{~b})$. Other striking examples of a lack of correspondence in relative abundances are provided by $G$. fortis and $G$. scandens; they are rare as fossils and abundant in modern collections and finch communities (Abbott, Abbott \& Grant, 1977; Smith et al., 1978). Their scarcity as fossils cannot be attributed to their avoidance by owls (Grant, P. R. et al., 1975).

\section{Why have no more species evolved?}

Lack $(1945,1947)$ pointed out that large islands have more finch species than small ones. In several subsequent studies a statistical relationship has been established between number of species and island area (Hamilton \& Rubinoff, 1963, 1964, 1967; Harris, 1973; Power, 1975; Abbott et al., 1977; Connor \& Simberloff, 1978). Finch species diversity is also correlated with food resource diversity. The reasons for the relationships are usually discussed in the context of the equilibrium theory of island biogeography, that is in terms of immigration and extinction (MacArthur \& Wilson, 1963, 1967). For a group of species that have evolved from a common ancestor in an archipelago, like Darwin's finches, the question that is usually not addressed is why the relationship between species number and island takes its particular form and no other. Why, for example, are there three species of finches on I. Española, eight on I. Floreana and ten on I. Isabela, and not 6,16 and 20 on them respectively?

The two types of answers are (a) there has not been sufficient time for the evolution of 20 or more species, and (b) the archipelago is 'saturated' with species, and the upper limit to the number of species on each island and in the 
archipelago as a whole, set by ecological constraints, has been reached already.

Evidence for the first hypothesis comes from an attempt to predict the maximum number of co-existing ground finch species from the theory of limiting similarity (Grant, P. R., 1983b). A knowledge of the range of sizes of mainland species of finches, and the spacing rule of island species on a bill size axis, leads to the prediction that a maximum of seven species of ground finch species should co-exist. In fact only five co-exist (see Fig. 6). Ecological explanations for the absence of two species were sought and not found, therefore an hypothesis of insufficient time was tentatively accepted (Grant, P. R., 1983b). However the ecological data were crude, and the analysis was more revealing in identifying areas of ignorance than in providing support for a particular hypothesis.

Other and stronger evidence supports the alternative hypothesis of saturation. First, as discussed above, it is likely that there has been sufficient time for more than 14 species to evolve, as possibly two or more species have become extinct. Second, the potential for evolutionary change exists in present species: there is enough additive genetic variance underlying phenotypic variation in mensural traits for selection to act on in such a way as to result in the formation of a new species. Third, ecological data suggest that islands have as many finch species as they can sustain over long periods of time.

To amplify the second point, consider the absence of a micro Geospiza species pinpointed by the analysis in Fig. 6. For this missing species to evolve, selection should effect a $15 \%$ reduction in the size of $G$. fuliginosa. Heritabilities of quantitative morphological traits (beak size and body size) are probably large in this species, because they are known to be large in the related species $G$. fortis and G. conirostris (Boag \& Grant, 1978; Boag, 1983; Grant, P. R. \& Price, 1981; Grant, 1981a, in press a). Furthermore a selective shift of about $6 \%$ in morphological traits has been witnessed in the space of one year in the population of $G$. fortis on I. Daphne Major (Boag \& Grant, 1981, in press). As finches depleted the non-renewed food supply of mainly small seeds during the drought of 1977, only those with large bills were capable of cracking the relatively large seeds that remained in moderate abundance, and they survived at a higher frequency than did those with small bills. Genetic variation governing bill size and body size was not detectably reduced during this episode of directional selection: heritabilities of all traits remained large (Boag, 1983).

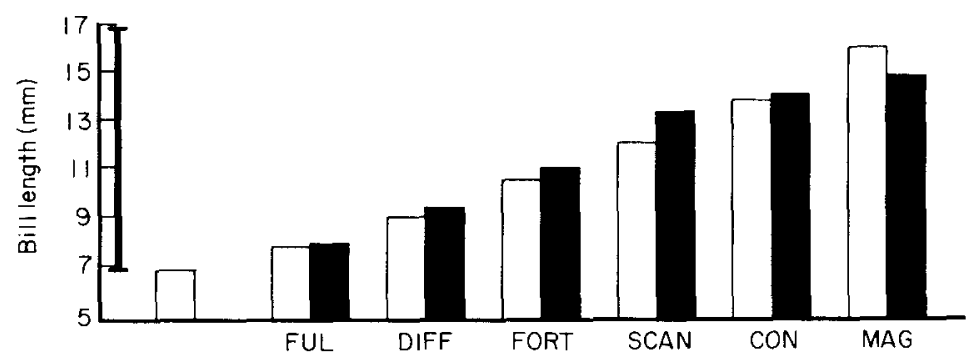

Figure 6. Bill lengths of ground finch species on the Galapagos (Grant, 1983b) Open bars show lengths predicted from limiting similarity theory (see text) and from the possible range of lengths indicated by the vertical line. Solid bars show the observed bill lengths of the six species in the genus Geospiza: fuliginosa (FUL), difficilis (DIFF), fortis (FORT), scandens (SCAN), conirostris (CON) and magnirostris (MAG). Note the absence of the smallest possible finch species. For further details see Grant (1983b). 
Therefore the potential for further evolutionary change was present, and in fact realized (Price, in press a \& b; Price \& Grant, in press; Price, Grant \& Boag, in press).

Given high heritabilities and strong selection, it is not difficult to envisage a selective shift in bill size and body size of $15 \%$ over a period of, say, 50-100 years. The fact that a micro- Geospiza species does not occur anywhere in the archipelago therefore suggests that the appropriate regime of selection does not exist. In other words, the feeding niche for such a species does not exist. Small seeds are consumed by $G$. fuliginosa, and the population sizes of this species on various islands are well predicted by the abundance of small seeds on those islands (Schluter \& Grant, in press a). Searching for vacant niches is not a rewarding exercise, and the wealth of data on the feeding ecology of the ground finches obtained in the last decade (Grant, P. R. et al., 1976; Abbot et al., 1977; Smith et al., 1978, Grant, B. R. \& Grant, P. R., 1979, 1981, 1982; Grant, P. R. \& Grant, B. R., 1980a, 1980b; Grant, P. R., 1981b; Grant, P. R. \& Schluter, in press, Schluter \& Grant, 1982, in press a \& b; Schluter, 1982a, 1982b; Boag \& Grant, in press; Millington \& Grant, 1983) does not suggest that one will be found.

The third class of evidence for saturation is ecological. There are non-random distributional features of species in the genus Geospiza that can be interpreted as the product of interspecific competition. The outcome of competition between two, closely related, ecologically similar species has been the extinction of one of them. The result of competitive exclusion has been referred to as differential colonization (Grant, P. R., 1969; Grant, P. R. \& Abbott, 1980) or size assortment (Case \& Siddell, 1983). It has been an important process in the adjustment of species number to island size.

The evidence for differential colonization is as follows. First, combinations of Geospiza species are non-random; some combinations occur more frequently and others less frequently than expected by chance (Abbott et al., 1977; Simberloff \& Connor, 1981; Grant, P. R., 1981c; Grant, P. R. \& Schluter, in press, Simberloff, 1983). Second, those that are under-represented are combinations of species that are morphologically and ecologically similar to each other (Grant, P. R. \& Schluter, in press). Third, each of the six Geospiza species occurs with its most similar congener on fewer islands than average (Grant, P. R. \& Schluter, in press). Fourth, there is a statistically significant under-representation of species/genus on islands compared with what would be expected from a random distribution of species in all genera (Strong, Szyska \& Simberloff, 1979; Grant, P. R. \& Abbott, 1980; Grant, P. R., 1981c). The trends for Camarhynchus species are weaker (Power, 1975; Strong, Szyska \& Simberloff, 1979; Hendrickson, 1981; Alatalo, 1982; Case \& Siddell, 1983). Interpretation of these results in terms of competition between closely related species is dependent upon the strength of the assumptions of the analyses and the statistical adequacy of the tests. These topics have been discussed extensively by Abbott et al., 1979; Simberloff, 1978, in press; Connor \& Simberloff, 1978; Strong et al., 1979; Grant, P. R. \& Abbott, 1980; Grant, P. R., 1981c, 1983b; Hendrickson, 1981; Strong \& Simberloff, 1981; Simberloff \& Connor, 1981; Simberloff \& Boecklin, 1981; Alatalo, 1982; Grant, B. R. \& Grant, P. R., 1982; Schluter \& Grant, 1982; Schoener, 1982, in press; Case \& Siddell, 1983; Colwell \& Winkler, in press; Grant \& Schluter, in press.

The evidence of differential colonization supports the hypothesis that a particular island is saturated with species or close to that state. It does not throw 
light on the question of whether the archipelago is saturated with species or not. To take the extreme case, why are there not many more species of Darwin's finches, each restricted to one island? Part of the answer lies in the recurrent patterns of resource frequency distributions among islands (Abbott et al., 1977; Schluter \& Grant, in press a). Another part of the answer is that species evolved sequentially and not simultaneously. A third part is that each speciation event was followed by dispersal of the new species to other islands, and colonization of those that had the food resources which the new species was able to exploit. Thus each speciation event followed by dispersal brought the number of species in the archipelago closer to the maximum sustainable (Fig. 4). This argument is qualitative, and needs to be put into quantitatively testable form (see also Hamilton \& Rubinoff, 1964, 1967).

In conclusion, lack of ecological opportunity, rather than lack of evolutionary time, is the best current explanation for why there are no more than 13 species of Darwin's finches on the Galapagos.

\section{How is the adaptive differentiation explained?}

This is the last and largest question. How can we account for the evolution of 13 species from a single ancestral species, and how can we account for their morphological, behavioural, ecological and distributional properties? These were the major questions dealt with by Lack $(1945,1947)$, and to a lesser extent by Bowman (1961).

Lack $(1945,1947)$ proposed a model of repeated speciation events (see also Grant, P. R., 1981c, for elaboration) that involved two phases: an allopatric phase in which populations of the same species on different islands underwent a small amount of evolutionary divergence, and a secondary sympatric phase in which selection reinforced and amplified the initial divergence of the original and derived populations, thereby minimizing both competition for food and interbreeding (Fig. 7). In Lack's language, speciation involved the development of ecological isolation and reproductive isolation between two populations.

Both the ecological and reproductive relationships between closely related species in the ground finch group have been the focus of much recent research. Other aspects of the adaptive differentiation of the finches have not been studied in as much detail.

\section{Ecological isolation}

Adaptive morphological differentiation of populations of the same species begins in allopatry. This is suggested by the marked differences in the food supplies on different islands (Bowman, 1961; Abbott et al., 1977; Smith et al., 1978; Boag \& Grant, in press; Schluter \& Grant, in press a \& b), something which Lack (1947) initially overlooked, later explicitly acknowledged (Lack, 1969) but largely ignored (Lack, 1971). Evolution in allopatry is more directly demonstrated by documenting interisland variation in morphology, and showing that such variation is correlated with ecological variation (Grant, B. R. \& Grant P. R., 1982; Schluter \& Grant, 1982, in press a \& b; Boag \& Grant, in press).

Lack (1947) argued that competition for food occurred between original and derived populations in the sympatric phase of the speciation process. Bowman 


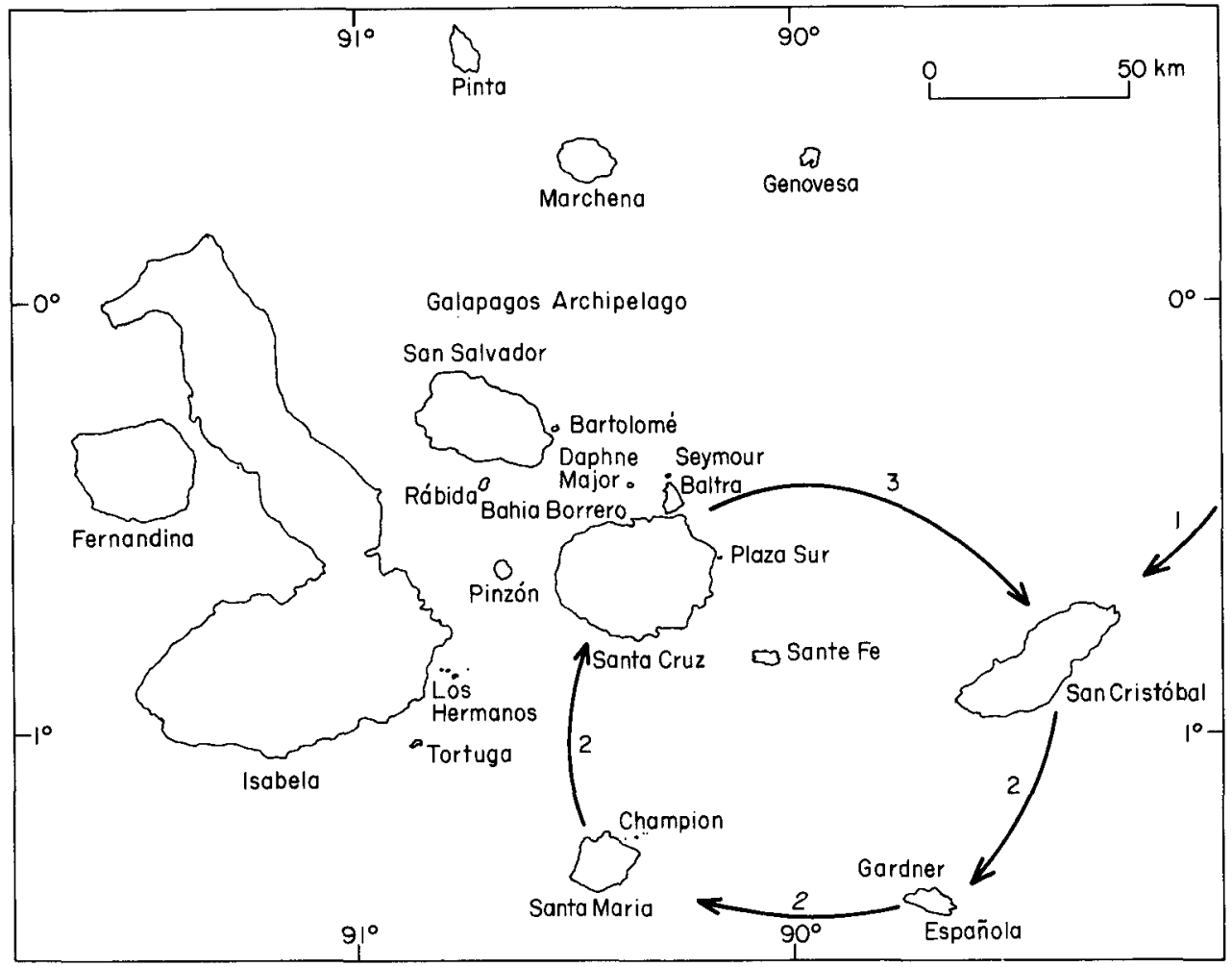

Figure 7. A representation of the allopatric model of speciation (after Grant, 1981c). Immigrants from the mainland colonized an island in step 1. Then dispersal to other islands took place, perhaps repeatedly, in step 2. In step 3 members of one of the derived populations colonized the original island and became established as a new species, interbreeding little if at all with members of the original population. Thus two species were formed from one, and in step 4 (not shown) the cycle of events was repeated several times with the eventual formation of at least 13 species, possibly more (see Fig. 4). The choice of islands to illustrate the model is arbitrary.

(1961) put forward the alternative view that competition did not occur because large ecological differences acquired in the allopatric phase enabled the populations to co-exist without interaction in the sympatric phase. The conflict of views and its resolution have been discussed in detail (Grant, P. R., 1981c, 1983b; Grant, B. R. \& Grant, P. R., 1982). It is only summarized here.

Lack's evidence for competition was non-quantitative and, necessarily, inferential. For example he pointed to the apparently regular spacing of sympatric species of ground finches on a bill size axis on large islands, and the intermediate position of solitary species on this axis on small islands. Such regular spacing, and the inferred corollary of regular spacing along an axis of food size (see Abbott et al., 1977 for evidence), is often used to draw conclusions about the over-dispersion of ecological niches as a result of competitive interaction (Schoener, 1974). However, given the small number of species involved in each analysis, it is not easy to detect non-random spacing along an axis. Efforts to apply statistics to data (Simberloff \& Boecklin, 1981) have been criticized for their unrealistic assumptions (Schoener, in press).

Co-existing species of the genus Geospiza always differ in at least one bill dimension by at least 15\% (Grant, P. R., 1981c, 1983b). This is consistent with 
an hypothesis of competition (Grant, P. R., 1981c), but a statistical null hypothesis has not been constructed and tested with this set of data. Instead, patterns of morphological variation among sympatric species have been quite accurately predicted from models based on food supply that incorporate the effects of competition. Models that do not include competitive effects do not make such accurate predictions (Schluter \& Grant, in press a).

Nevertheless there are statistically non-random features of the morphology and distribution of the six ground finch species. Eleven of the 13 pairs of Geospiza species that co-exist differ morphologically more in sympatry than in allopatry (Fig. 8). Such a high proportion is not expected by chance (Grant, P. R., 1981c, 1983b). Morphological differences between $G$. fortis and $G$. fuliginosa, the two species that co-exist most frequently, are significantly greater in sympatry than would be expected if all their populations had been randomly combined in pairs (Grant, P. R. \& Schluter, in press). These two analyses provide evidence of character displacement, that is enhanced morphological, and presumed ecological, differences in sympatry as a result of evolutionary changes of one or both species. The interplay between food factors and competition, and its evolutionary effect upon the finches, is discussed more fully in Schluter \& Grant (in press a).

The overall conclusion from these tests and from those discussed on p. 124, is that interspecific competition has occurred in the past, and has left its mark on

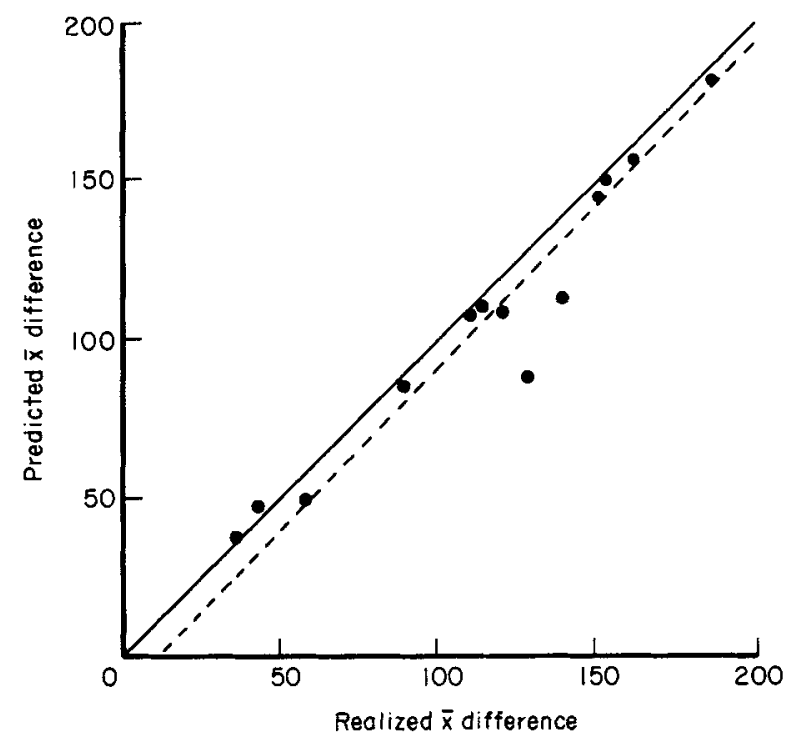

Figure 8. Prediction of multivariate beak differences, in arbitrary units, between co-occurring Geospiza congeners from a model of random combination of species. The predicted average differences between co-existing species are the differences between species means for all island populations, whether they co-exist or not, and realized differences are averages of the actual differences between co-existing populations of those species: thus sympatric populations (realized) are compared with sympatric and allopatric populations (predicted). If predictions were correct in all cases, all points would lie along the solid line; the broken line is a least squares best fit to the points. Most beak differences are greater than predicted (see text). Geospiza conirostris and $G$. scandens are predicted to occur with a multivariate difference of 67 units, and for $G$. conirostris and $G$. fortis the predicted difference is 83 units, but neither of these species pairs actually occurs on an island. These results were first presented in a symposium in 1977 (Grant, 1983b). 
the morphological and distributional features of the finches. Lack's (1945, 1947) hypothesis of competitive interaction in the sympatric phase of the speciation processes is thus supported by the results of these quantitative tests.

\section{Reproductive isolation}

Lack's $(1945,1947)$ hypothesis postulates character displacement (divergence Grant, P. R., 1972) in courtship signals at the time of secondary contact between original and derived populations. At the start of the process, certain properties of individuals functioned as cues, signalling information about the group (population) to which those individuals belonged, with a degree of ambiguity in proportion to the lack of group-distinctiveness of the cues. At the end of the process of divergence under selection, the ambiguity had diminished or disappeared. Presumably the response systems also diverged under selection, with the end result being complete reproductive isolation of the two groups, now species. At this point the cues are species-specific.

Testing this hypothesis requires identification of courtship signals that convey species-specific information to the receiver. All species of Darwin's finches engage in similar postures and acts in courtship (Orr, 1945; Lack, 1947), and if there are reliable differences among species they are quantitative and hitherto undetected. Within some groups of finch species, such as the ground finch species, plumages are the same. Lack $(1945,1947)$ suggested that the most reliable cues conveying information about species identity are the ones we use, namely morphological cues and in some instances specifically bill shape. His experiments with stuffed speciments of $G$. fortis and $G$. fuliginosa supported this suggestion. However the large amount of inter-individual variation in response necessitates a repeat and extension of these experiments, which Ratcliffe (1981) has performed.

The role of morphological cues in species recognition was confirmed by the results of experiments conducted on several islands with Geospiza species. Discrimination by responding birds was tested in experiments each with two stuffed specimens. Males and females (of different species) responded more aggressively towards male conspecific specimens than to sympatric heterospecific ones (Ratcliffe \& Grant, 1983a). Males preferentially courted conspecific females during experiments (and in natural encounters). Therefore species recognition by males responding to morphological cues is an important component of premating isolation in the genus. Results of an incomplete series of experiments suggested that recognition depends on combined morphological stimuli from head and body, rather than on stimuli from head alone (such as bill shape).

The reinforcement hypothesis of Lack can be tested with stuffed specimens. The hypothesis makes the prediction that males from sympatric populations should show significantly stronger sexual preferences for conspecific females than would males from allopatric population given the same choice situation. The prediction was tested and upheld by the results of experiments carried out with Geospiza species on different islands (Ratcliffe \& Grant, 1983b).

Some of the species were more different in morphology when sympatric than when allopatric. But on I. Pinta the two species tested ( $G$. fuliginosa and $G$. difficilis) were no more different from each other than were their tested allopatric populations, yet preference for conspecific females was enhanced in 
the sympatric populations. This result shows that the discrimination behaviour itself is different among island populations of the same species even when differences in the signals are the same among those populations. The question then arises as to whether enhanced discrimination in sympatry is the result of the experience of seeing heterospecifics, and possibly courting them without reward, or whether it represents an evolutionary change of behaviour. This question is unanswered by the experiments. But an evolutionary change is suggested by the enhanced ability to discriminate shown by $G$. fuliginosa living in the lowlands of I. Pinta where G. difficilis is virtually absent (Schluter, 1982a, 1982b; Schluter \& Grant, 1982).

The reinforcement hypothesis also leads to the expectation of reproductive 'confusion' and hence interbreeding between a resident species and immigrants from another island of the same species, or of a similar and relatively undifferentiated species. A long-term field study of $G$. fortis on I. Daphne Major has yielded evidence of repeated but infrequent hybridization. Of all populations of $G$. fortis this one most resembles an allopatric species, G. fuliginosa. Small numbers of $G$. fuliginosa immigrate to I. Daphne where they rarely hybridize with $G$. fortis but do not establish themselves as a breeding population (Boag, 1981; Grant, P. R. \& Price, 1981). In choice tests with stuffed specimens, G. fortis on this island show no discrimination between conspecifics and G. fuliginosa. Therefore, in agreement with the hypothesis, reproductive confusion exists, apparently as a consequence of morphological similarity.

Females rarely respond to stuffed specimens of males. Males, but not females, sing. Therefore song may also convey species-specific information, and female choice of males may be based partly or wholly on male song. Lack (1947) believed that song was too variable to be used by females as a reliable indicator of species identity. Bowman $(1979,1983)$ and Ratcliffe (1981) have used sonagraphic analysis to document song variation among and within species. These studies show that on most islands species usually sing different songs, although quantitative analyses establish a lack of discreteness in the structural features of the songs of different species on one or two islands (Ratcliffe, 1981). Moreover, song is less reliable as a species recognition cue than are some morphological cues since it is culturally acquired and mis-imprinting occasionally occurs (Bowman, 1979, 1983; Ratcliffe, 1981). This casts doubt on Bowman's (1983) untested hypothesis that female finches identify conspecific males chiefly by their song during courtship.

Species recognition by song has been tested experimentally with Geospiza species (Ratcliffe \& Grant, in press). The results show that males of different species can discriminate between conspecific and heterospecific song in the absence of morphological cues. When morphological and song cues were presented simultaneously to test birds in a short series of experiments, the results were ambiguous. The general conclusion, however, is that both morphological and song cues can be, and probably are, used by birds in choosing a mate. And in choosing a mate, birds discriminate between members of their own and members of a different species more strongly when the heterospecifics are resident on the same island than when they are immigrants from another island.

It is a fundamental assumption of Lack's reinforcement hypothesis that between-group matings yield fewer offspring per capita that contribute to the 
next generation than do within-group matings. The significance of visual discrimination in a sexual context during the experiments may be interpreted (Ratcliffe \& Grant, 1983a) as a reflection of an individual's preference for a potential mate with high fitness prospects (i.e. a conspecific) rather than low fitness prospects (i.e. a heterospecific). Since hybrids are generally intermediate in morphology between parental phenotypes (Boag, 1981) it is reasonable to assume that such individuals have reduced chances of surviving the Galapagos dry season when finch diets diverge interspecifically as food becomes scarce and probably limiting to population sizes (Smith et al., 1978; Grant, P. R. \& Grant, B. R., 1980a, 1980b; Boag \& Grant, 1981, in press; Schluter, 1982b). However reduced fitness of hybrids and their parents has not yet been demonstrated (Boag, 1981; Grant \& Price, 1981).

Hybridization also occurs between resident Geospiza species (Boag, 1981; Grant, P. R. \& Price, 1981; Grant, B. R. \& Grant, P. R., 1982; Boag \& Grant, in press), although at a frequency of $1 \%$ or less (see also Lack, 1945, 1947; Bowman, 1961; Harris, 1973). This means that reproductive isolation between several pairs of species is not perfect. The unanswered question for future research is the basis, or bases, of mate selection. If heterospecifics are usually avoided as potential mates why are they not always avoided, and within the range of acceptable conspecific mates what is it that governs which particular individuals will be chosen? Mis-imprinting has been implicated as the cause of the rare pairings between resident species (Boag, 1981; Ratcliffe, 1981; Grant, B. R. \& Grant, P. R., 1982). Within Geospiza species there does not appear to be a pronounced tendency for mate choice to be based on either morphological or song cues (Grant, B. R. \& Grant, P. R., 1979, 1983; Boag, 1983; Grant, B. R. in press; Millington, Price \& Ratcliffe, in prep.), although two exceptions to this have been observed. In the first instance there was a weak positive association between $G$. fortis mates in mensural traits on I. Daphne Major in 1976, when the sex ratio was approximately 1 : 1 (Boag \& Grant, 1978; Boag, 1981, 1983). The association has not been observed in any year since 1977, when males have consistently outnumbered females. However, in the second instance females have paired preferentially with large males during times of an unequal sex ratio, suggesting that mate choice was based either on male size or on the correlated traits of degree of blackness in the plumage and territory size (Price, in press a; see also Millington \& Grant, 1983).

Lack (1945) initially attributed all differences in bill shape between morphologically similar species of finches to selection-reinforcing reproductive isolation. He later reinterpreted bill shape differences primarily in terms of selection for ecological isolation (Lack, 1947). Two recently established facts suggest that Lack's final emphasis was right. First, selection favoured largebilled $G$. fortis on I. Daphne Major in 1977, because they had a feeding advantage over the remainder of the population during a drought when breeding did not occur (Boag \& Grant, 1981, in press). This study of selection in action complements inferences made about selection from numerous studies of the relationship between beak size and diets (e.g. Grant, P. R. et al., 1976; Abbott et al., 1977; Smith et al., 1978; Grant, P. R., 1981b; Grant, B. R. \& Grant, P. R., 1981, 1982; Schluter \& Grant, in press a \& b; Boag \& Grant, in press; Grant \& Schluter, 1983). Second, discrimination experiments on I. Pinta (Ratcliffe \& Grant, 1983b) show that reproductive isolation may be 
brought about by the enhancement of the ability to discriminate and not necessarily by the divergence of morphological features. The principally ecological determination of morphological differences between species (Schluter \& Grant, in press a) renders most of the theoretical objections to the hypothesis of reinforcement of reproductive isolation (Templeton, 1981) inapplicable here.

To summarize, recent observational and experimental results support Lack's reasoning about natural selection operating upon incipient species in sympatry. This does not mean that selection operated in the postulated way at all secondary contacts. In some cases substantial reproductive and ecological differences between species may have evolved in allopatry. But the evidence shows that divergence in ecological and reproductive traits occurred often enough to leave its mark on the properties of modern finch communities.

\section{Some current and future developments}

Evolutionary research on Darwin's finches in the last ten years has largely attempted to provide explanations for facts known to David Lack 35 years ago. Much of the research has involved fieldwork, including long-term population studies. These have yielded new facts. For example, it is now known that the interspecific pattern of egg size in relation to body size is quite different in Darwin's Finches from the pattern among continental finches living in a climatically similar habitat (Fig. 9). Clearly the difference represents an evolutionary shift on the islands that needs to be explained (Grant, P. R., 1982, 1983c). Another example is a colour polymorphism in the bills of young finches (Grant, P. R., et al., 1979). It may be, as in domestic fowl, under simple genetic control. This has yet to be established. But if it is under simple genetic control it could be a useful tool for studying genetic processes within populations. The frequency of the colour morphs is known to vary between species, between populations of the same species (Grant, P. R. et al., 1979), and between segments of a single population in an interesting way (Grant, B. R. \& Grant, P. R., 1979, 1983).

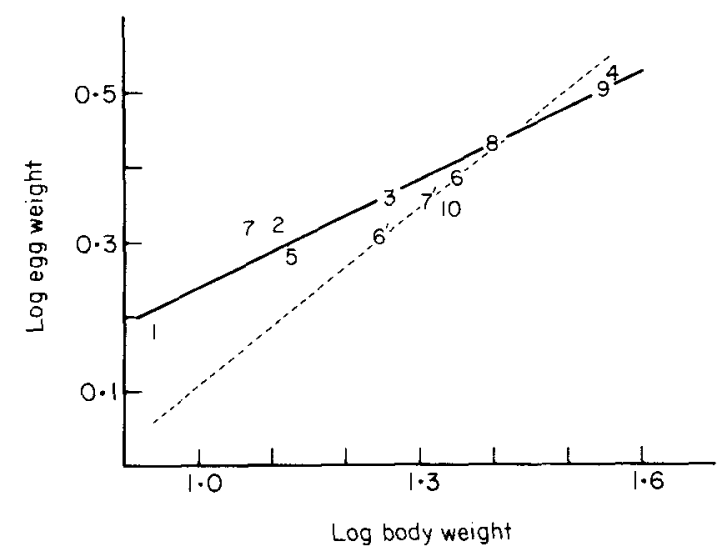

Figure 9. Relationships between log mean egg weight and mean body weight for Darwin's finches on the Galapagos and for a group of continental finches in a climatically similar part of Peru. The relationship for 12 numbered populations of 10 Darwin's finch species (slope 0.55 ) is shown by a solid line (see Grant, 1982 for population identities). The relationship for the six mainland species (slope 0.81 ) is shown by a broken line (Grant, 1983c). 
Studies of life history traits such as clutch size and development patterns (Downhower, 1978; Grant, P. R. \& Grant, B. R., 1980a; Boag, 1981; Grant, P. R., 1981a; Grant, B. R. \& Grant, P. R., 1983; Grant, P. R. in press a), and of natural selection acting on morphological traits with which the life history traits are correlated (Price \& Grant, in press), are beginning to reveal the previously unsuspected dynamic nature of Darwin's finch populations. They are showing not only large fluctuations in numbers as a result of climatic fluctuations (Grant, P. R. \& Grant, B. R., 1980b; Grant, P. R. \& Boag, 1980; Grant, P. R., in press, b), but pervasive natural selection (Grant, P. R. et al., 1976; Boag \& Grant, 1981; Grant, P. R. \& Price, 1981; Price, in press b; Price, Grant \& Boag, in press) and sexual selection (Price, in press a) operating on populations structured by age, size and song type (Grant, B. R. \& Grant, P. R., 1979, 1983; Price, in press a). These studies have the potential of explaining why Darwin's Finches are sexually dimorphic in size (Downhower, 1976; Price, in press b; why some species are sexually dichromatic and others are not; why males generally have a more conspicuous plumage than females and why rate of acquisition of fully adult plumage varies among males in a population (Price, in press a); and why some populations are so variable in bill size and body size (Ford, Parkin \& Ewing, 1973; Grant, P. R. et al., 1976; Grant, B. R. \& Grant, P. R., 1979, 1983; Grant, P. R. \& Price, 1981). Studies of genetic and demographic processes can deepen our understanding of both adaptation and speciation.

\section{THIS IS THE HOUSE THAT LACK BUILT}

Lack's (1945), 1947) monograph on Darwin's finches may be likened to an edifice. It was built on the same site, with the same materials and around the same pillars and struts as Darwin's much simpler construction erected a century earlier. New materials were supplied by Swarth $(1931,1934)$ and others, and incorporated with the aid of a blueprint sketched by Stresemann (1936). It was extremely well-built and modern for its time, being widely adopted as the archetype of a new style. How well has it fared since then?

It is still standing. It has not been replaced but has been transformed. It suffered storm damage in the early $1960 \mathrm{~s}$ and late $1970 \mathrm{~s}$. This has been repaired. Rotten planking has been replaced. Bricks had been put in back to front, and in the wrong place. These errors have been corrected. Structurally it is the same building, but it stands on a firmer foundation now. It has been thoroughly overhauled, modernized, elaborated and extended. Architectural details of the revisions and extensions have been published by L. M. Ratcliffe and P. T. Boag as a foreword to Lack (1983). The house of evolution has evolved.

\section{ACKNOWLEDGEMENTS}

I thank the Royal Society of London for a travel grant that enabled me to participate in the symposium on Evolution in the Galapagos Islands. Further support came from National Science Foundation (U.S.A.) grant DEB 79-21119. The organizer of the symposium, R. J. Berry, helped in numerous ways which I greatly appreciate. I thank I. Abbott, B. R. Grant, D. Schluter and D. W. Steadman for advice on the manuscript. 


\section{REFERENCES}

ABBOTT, I. \& ABBOTT, L. K., 1978. Multivariate study of morphological variation in Galápagos and Ecuadorean mockingbirds. Condor, 80: 302-308.

ABBOTT, I., ABBOTT, L. K. \& GRANT, P. R., 1977. Comparative ecology of Galápagos Ground Finches (Geospiza Gould): evaluation of the importance of floristic diversity and interspecific competition. Ecological Monographs, 47: 151-184.

ALATALO, R., 1982. Bird species distributions in the Galápagos and other archipelagos: competition or chance? Ecology, 63: 881-887.

BAILEY, K., 1976. Potassium-argon ages from the Galapagos Islands. Science, 192: 465-467.

BARROWCLOUGH, G. F., 1983. Biochemical studies of microevolutionary processes. In A. H. Brush \& G. A. Clark (Eds), Perspectives in Ornithology. Cambridge: University Press.

BOAG, P. T., 1981. Morphological variation in the Darwin's Finches (Geospizinae) of Daphne Major Island, Galápagos. Unpubl. Ph.D, thesis, McGill Univ., Montreal.

BOAG, P. T., 1983. The heritability of external morphology in Darwin's Ground Finches (Geospiza) on Isla Daphne Major, Galápagos. Evolution, 37: 877-894.

BOAG, P. T. \& GRANT, P. R., 1978. Heritability of external morphology in Darwin's Finches. Nature, 274: 793-794.

BOAG, P. T. \& GRANT, P. R., 1981. Intense natural selection in a population of Darwin's Finches (Geospizinae) in the Galápagos. Science, 214: 82-85.

BOAG, P. T. \& GRANT, P. R. (in press). The classical case of character release: Darwin's Finches (Geospiza) on Isla Daphne Major, Galápagos. Biological Journal of the Linnean Society.

BOWMAN, R. I. 1961. Morphological differentiation and adaptation in the Galápagos finches. University of California Publications in Zoology, 58: $1-302$.

BOWMAN, R. I. 1979. Adaptive morphology of song dialects in Darwin's Finches. Fournal für Ornithologie, 120: $353-389$.

BOWMAN, R. I. 1983. The evolution of song in Darwin's Finches. In A. E. Leviton \& R. I. Bowman, (Eds), Pattems of evolution in Galápagos organisms: 237-537. Special Publication, American Association for the Advancement of Science, Pacific Division, San Francisco.

BOWMAN, R. I. \& CARTER, A., 1971. Egg-pecking behavior in Galápagos mockingbirds. Living Bird, 9: $243-270$.

BROWN, J. L., 1974. Alternative routes to sociality in jays - with a theory for the evolution of altruism and communal breeding. American Zoologist, 14: 63-80.

BROWN, J. L. 1978. Avian communal breeding systems. Annual Reviews of Ecology and Systematics, 9: 123-156.

CASE, T. J. \& SIDELL, R., 1983. Pattern and chance in the structure of model and natural communities. Evolution, 37: 832-849.

COLWELL, R. K. \& WINKLER, D., in press. A null model for null models in evolutionary ecology. In D. R. Strong, D. S. Simberloff, A. B. Thistle \& L. G. Abele (Eds), Ecological Communities: Conceptual Inssues and the Evidence. Princeton: University Press.

CONNOR, E. G. \& SIMBERLOFF, D. S., 1978. Species number and compositional similarity of the Galápagos flora and avifauna. Ecological Monographs, 48: 219-248.

COX, A., 1983. Ages of the Galápagos Islands. In R. I. Bowman, M. Berson \& A. E. Leviton (Eds), Patlerns of evolution in Galápagos organisms: 11-23. Special Publication, American Association for the Advancement of Science, Pacific Division, San Francisco.

CUTLER, B. D., 1970. Anatomical siudies on the syrinx of Darwin's finches. Unpubl. M.A. thesis, San Francisco State Univ., San Francisco.

De VRIES, Tj. 1975. The breeding biology of the Galápagos Hawk, Buteo galapagoensis. Le Gerfaut, 65: 29-58.

De VRIES, Tj. 1976. Prey selection and hunting methods of the Galápagos Hawk, Buteo galapagoensis. Le Gerfaut, 66: 3-42.

DOWNHOWER, J. F., 1976. Darwin's Finches and the evolution of sexual dimorphism in body size. Nature, 263: $558-563$.

DOWNHOWER, J. F., 1978. Observations on the nesting of the small ground finch Geospiza fuliginosa and the large cactus ground finch G. conirostris on Espanola, Galápagos. Ibis, I20: 340-346.

EMLEN, S., 1978. The evolution of cooperative breeding in birds. In J. R. Krebs \& N. B. Davies (Eds), Behavioral Ecology: an Evolutionary Approach. Massachusetts: Sinauer.

EMLEN, S., 1982a. The evolution of helping. I. An ecological constraints model. American Naturalist, 119: 29-39.

EMLEN, S., 1982b. The evolution of helping. II. The role of behavioral conflict. American Naturalist, 119: 40-53.

FAABORG, J., DE VRIES, Tj., PATTERSON, C. B. \& GRIFFIN, C. R., 1980. Preliminary observations on the occurrence and evolution of polyandry in the Galápagos Hawk (Buieo galapagoensis). Auk, 97: 581-590.

FAABORG, J. \& PATTERSON, C. B., 1981. The characteristics and occurrence of cooperative polyandry. Ibis, 123: $477-484$. 
FORD, H. A., EWING, A. W. \& PARKIN, D. T., 1974. Blood proteins in Darwin's Finches. Comparative Biochemistry and Physiology, 47B: 369-375.

FORD, H. A., PARKIN, D. T. \& EWING, A. W., 1973. Divergence and evolution in Darwin's Finches. Biological fournal of the Linnean Society 5: 289-295.

FRANKLIN, A. B., CLARK, D. A. \& CLARK, D. B., 1979. Ecology and behavior of the Galápagos Rail. Wilson Bulletin, 91: 202-221.

GRANT, B. R. (in press). The significance of song variation in a population of Darwin's Finches. Behaviour.

GRANT, B. R. \& GRANT, P. R. 1979. Darwin's finches: population variation and sympatric speciation. Proceedings of the National Academy of Sciences, USA, 76: 2359-2363.

GRANT, B. R. \& GRANT, P. R., 1981. Exploitation of Opuntia cactus by birds on the Galápagos. Oecologia, 49: $179-187$.

GRANT, B. R. \& GRANT, P. R., 1982. Niche shifts and competition in Darwin's Finches: Geospiza conirostris and congeners. Evolution, 36: 637-657.

GRANT, B. R. \& GRANT, P. R., 1983. Fission and fusion in a population of Darwin's Finches: an example of the value of studying individuals in ecology. Oikos, 41: 530-547.

GRANT, P. R., 1969. Colonization of islands by ecologically dissimilar species of birds. Canadian Journal of Zoology, 47: $41-43$.

GRANT, P. R., 1972. Convergent and divergent character displacement. Biological Journal of the Linnean Society, $4: 39-68$.

GRANT, P. R., 1981 a. Patterns of growth in Darwin's Finches. Proceedings of the Royal Society of London B, 212: 403-432.

GRANT, P. R., 1981b. The feeding of Darwin's Finches on Tribulus cistoides (L.) seeds. Animal Behaviour, 29: 785-793.

GRANT, P. R., 1981c. Speciation and the adaptive radiation of Darwin's Finches. American Scientist, 69: $653-663$.

GRANT, P. R., 1982. Variation in the size and shape of Darwin's Finch eggs. Auk, 99: 15-23.

GRANT, P. R., 1983a. The endemic landbirds. In R. L. Perry (Ed.), The Galápagos. Key Environment series, vol. 1. Oxford: Pergamon.

GRANT, P. R., 1983b. The role of interspecific competition in the adaptive radiation of Darwin's Finches. In R. I. Bowman, M. Berson \& A. E. Leviton (Eds), Patterns of Evolution in Galapagos Organisms: 187-199. American Association for the Advancement of Science, Pacific Division, San Francisco.

GRANT, P. R., 1983c. The relative size of Darwin's Finch eggs. Auk, 100: 228-230.

GRANT, P. R. (in press a). Inheritance of size and shape in a population of Darwin's Finches, Geospiza conirostris. Proceedings of the Royal Society of London, $B$ :

GRANT, P. R. (in press b). Climatic fluctuations on the Galápagos islands and their influence on Darwin's Finches. Ornithological Monographs:

GRANT, P. R. \& ABBOTT, I., 1980. Interspecific competition, island biogeography, and null hypotheses. Evolution, 34: 332-341.

GRANT, P. R. \& BOAG, P. T., 1980. Rainfall on the Galápagos and the demography of Darwin's Finches. $A u k, 97: 227-244$.

GRANT, P. R., BOAG, P. T. \& SCHLUTER, D., 1979. A bill color polymorphism in young Darwin's Finches. Auk, 96: 800-802.

GRANT, P. R. \& GRANT, B. R., 1980a. The breeding and feeding characteristics of Darwin's Finches on Isla Genovesa, Galápagos. Ecological Monographs, 50: 381-410.

GRANT, P. R. \& GRANT, B. R., 1980b. Annual variation in finch numbers, foraging and food supply on Isla Daphne Major, Galápagos. Oecologia, 46: 55-62.

GRANT, P. R., GRANT, B. R., SMITH, J. N. M., ABBOTT, I. J. \& ABBOTT, L. K., 1976. Darwin's Finches: population variation and natural selection. Proceedings of the National Academy of Sciences USA, 73: 257-261

GRANT, P. R. \& GRANT, K. T., 1979. The breeding and feeding of the Galápagos dove, Zenaida galapagoensis. Condor, 81: 397-403.

GRANT, P. R. \& GRANT, N., 1979. Breeding and feeding of the Galápagos mockingbird, Nesomimus parvulus. Auk, 96: 723-736.

GRANT, P. R. \& PRICE, T. D., 1981. Population variation in continuously varying traits as an ecological genetics problem. American Zoologist, 21: 795-811.

GRANT, P. R. \& SCHLUTER, D., in press. Interspecific competition inferred from patterns of guild structure. In D. R. Strong, D. S. Simberloff, A. B. Thistle, \& L. G. Abele (Eds), Ecological Communities: Conceptual Issues and the Evidence. Princeton: University Press.

GRANT, P. R., SMITH, J. N. M., GRANT, B. R., ABBOTT, I. J. \& ABBOTT, L. K., 1975. Finch numbers, owl predation and plant dispersal on Isla Daphne Major, Galápagos. Oecologia, 19: 239-257.

HAMILTON, T. H. \& RUBINOFF, I, 1963. Isolation, endemism, and multiplication of species in the Darwin's finches. Evolution, 17: 388-403.

HAMILTON, T. H. \& RUBINOFF, I. 1964. On models predicting abundance of species and endemics for the Darwin finches in the Galápagos archipelago. Evolution, 18: 339-342.

HAMILTON, T. H. \& RUBINOFF, I., 1967. On predicting insular variation in endemism and sympatry for the Darwin's finches in the Galápagos archipelago. American Naturalist, 101: 161-172. 
HARRIS, M. P., 1972. Coereba flaveola and the Geospizinae. Bulletin of the British Ormithologists Club, 92: 164-168.

HARRIS, M. P., 1973. The Galápagos avifauna. Condor, 75: 265-278.

HARRIS, M. P., 1974. A Field Guide to Birds of Galapagos. London: Collins.

HATCH, J., 1966. Collective territories in Galápagos Mockingbirds, with notes on other behavior. Wilson Bulletin, 78: 198-206.

HENDRICKSON, J. A., Jr., 1981. Community wide character displacement reexamined. Evolution, 35: 794-809.

HEY, R., 1977. Tectonic evolution of the Cocos-Nazca sprcading center. Geological Society of America Bulletin, 88: $1404-1420$.

JO, N. 1983. Karyotypic analysis of Darwin's finches. In R. I. Bowman, M. Berson \& A. E. Leviton (Eds), Patterns of evolution in Galápagos organisms: 201-217. American Association for the Advancement of Science, Pacific Division, San Francisco.

KINNAIRD, M. F. \& GRANT, P. R., 1982. Cooperative breeding by the Galápagos Mockingbird, Nesomimus parvulus. Behavioral Ecology and Sociobiology, 10: 65-73.

LACK, D., 1945. The Galápagos finches (Geospizinae): a study in variation. Occasional Papers of the California Academy of Sciences, 21: 1-159.

LACK, D., 1947. Danwin's Finches. Cambridge: University Press.

LACK, D., 1969. Subspecies and sympatry in Darwin's Finches. Evolution, 23: 252-263.

LACK, D., 1971. Ecological Isolation in Birds. London: Methuen.

LACK, D. 1983. Darwin's Finches. Cambridge: University Press. Reprinting of Lack, D. 1947, with foreword by L. M. Ratcliffe \& P. T. Boag.

MACARTHUR, R. H. \& WILSON, E. O., 1963. An equilibrium theory of insular biogeography. Evolution, 17: $373-387$

MACARTHUR, R. H. \& WILSON, E. O., 1967. The Theory of Island Biogeography. Princeton: University Press.

MADER, W. J., 1979. Breeding behavior of a polyandrous trio of Harris's Hawks in southern Arizona. Auk, 96: 776-788.

MARCHANT, S. 1960. The breeding of some S. W. Ecuadorian birds. Ibis, 102: 349-381, 584-599.

MILLINGTON, S. J. \& GRANT, P. R., 1983. Feeding ecology and territoriality of the Cactus Finch Geospiza scandens on Isla Daphne Major, Galápagos. Oecologia, 58: 76-83.

MILLINGTON, S., PRICE, T. D. \& RATCLIFFE, L. M., in press. Song inheritance and mating patterns in two species of Darwin's Finches.

ORR, R. T., 1945. A study of captive Galápagos finches of the genus Geospiza. Condor, 47: 177-201.

POLANS, N., 1983. Enzyme polymorphisms in Galápagos finches. In R. I. Bowman, M. Berson \& A. E. Leviton (Eds), Patterns of evolution in Galapagos organisms: 219-235. American Association for the Advancement of Science, Pacific Division, San Francisco.

POWER, D., 1975. Similarity among avifaunas of the Galápagos Islands. Ecology, 56: 616-626.

PRICE, T. D., in press a. Sexual selection and body size, plumage and territory variables in a population of Darwin's finches. Evolution.

PRICE, T. D., in press b. The evolution of sexual size dimorphism in a population of Darwin's Finches. American Naturalist.

PRICE, T. D. \& GRANT, P. R., in press. Life history traits and natural selection for small body size in a population of Darwin's Finches. Evolution.

PRICE, T. D. in press. Genetic changes in the morphological differentiation of Darwin's Ground Finches. In K. Wörhmann \& V. Loshchke (Eds), Population Biology and Evolution. Berlin: Springer-Verlag.

PRICE, T. D., MILLINGTON, S. \& GRANT, P. R., 1983. Helping at the nest as misdirected parental care. Auk, 100: 192-194.

RATCLIFFE, L. M., 1981. Species recognition in Darwin's Ground Finches (Geospiza, Gould). Unpubl. Ph.D. thesis, McGill Univ., Montreal.

RATCLIFFE, L. M. \& GRANT, P. R., 1983a. Species recognition in Darwin's Finches (Geospiza, Gould). I. Discrimination by morphological cues. Animal Behaviour, 31: 1139-1153.

RATCLIFFE, L. M. \& GRANT, P. R., 1983b. Species recognition in Darwin's Finches (Geospiza, Gould). II. Geographic variation in mate preference. Animal Behaviour, 31: 1154-1165.

RATCLIFFE, L. M. \& GRANT, P. R. in press. Species recognition in Darwin's Finches (Geospiza, Gould). III. Male responses to playback of different song types, dialects and heterospecific songs. Animal Behaviour 32.

ROTHSCHILD, W. \& HARTERT, E., 1899. A review of the ornithology of the Galápagos islands. With notes on the Webster-Harris expedition. Novitates Zoologicae, 6: 85-205.

SARICH, V. M., 1977. Rates, sample sizes and the neutrality hypothesis for electrophoresis in evolutionary studies. Nature, 265: 24-28.

SCHLUTER, D., 1982a. Seed and patch selection by Galápagos ground finches: relation to foraging efficiency and food supply. Ecology, 63: 1106-1120.

SCHLUTER, D., 1982b. Distributions of Galápagos ground finches along an altitudinal gradient: the importance of food supply. Ecology, 63: 1504-1517.

SCHLUTER, D. \& GRANT, P. R., 1982. The distribution of Geospiza difficilis in relation to G. fuliginosa in the Galápagos islands: tests of three hypotheses. Evolution, 36: 1213-1226. 
SCHLUTER, D. \& GRANT, P. R. (in press a). Determinants of morphological patterns in communities of Darwin's Finches. American Naturalist.

SCHLUTER, D. \& GRANT, P. R. (in press b). Ecological correlates of morphological evolution in a Darwin's finch species, Geospiza difficilis.

SCHOENER, T. W., 1974. Resource partitioning in ecological communities. Science, 185: 27-39.

SCHOENER, T. W., 1982. The controversy over interspecific competition. American Scientist, 70: $586-595$.

SCHOENER, T. W., 1983. Size differences among sympatric, bird-eating hawks: a worldwide survey. In D. R. Strong, D. S. Simberloff, A. B. Thistle \& L. G. Abele (Eds), Ecological communities: conceptual issues and the evidence. Princeton: University Press.

SIBLEY, G. G. \& AHLQUIST, J. E., 1982. The relationships of the Hawaiian honeycreepers (Drepaninae) as indicated by DNA-DNA hybridization. Auk, 99: 130-140.

SIBLEY, C. G. \& AHLQUIST, J. E., in press. The phylogeny and classification of the passerine birds, based on comparisons of the genetic material, DNA. Proceedings of the 18th International Ornithological Congress (Moscow, 1982).

SIMBERLOFF, D., 1978. Using island biogeographic distributions to determine if colonization is stochastic. American Naturalist, 112: 713-726.

SIMBERLOFF, D., 1983. Morphological and taxonomic similarity and combinations of coexisting birds in two archipelagos. In D. R. Strong, D. S. Simberloff, A. B. Thistle \& L. G. Abele (Eds), Ecological communities: conceptual issues and the evidence. Princeton: University Press.

SIMBERLOFF, D. \& BOECKLEN, W., 1981. Santa Rosalia reconsidered: size ratios and competition. Evolution, 35: 1206-1228.

SIMBERLOFF, D. \& CONNOR, E. F., 1981. Missing species combinations. American Naturalist, 118: 215-239.

SMITH, J. N. M., GRANT, P. R., GRANT, B. R., ABBOTT, I. J. \& ABBOTT, L. K., 1978. Seasonal variation in feeding habits of Darwin's Ground Finches. Ecology, 59: 1137-1150.

STEADMAN, D. W., 1982a. The origin of Darwin's Finches. Transactions of the San Diego Society of Natural History, 19: 279-296.

STEADMAN, D. W., 1982b. Fossil birds, reptiles, and mammals from Isla Floreana, Galapagos archipelago. Unpubl. Ph.D. thesis, Univ. Arizona, Tucson.

STRESEMANN, E., 1936. Zur Frage der Artbildung in der Gatung Geospiza. Orgaan der Club Van Nederl. Vogel., 9: 13-21.

STRONG, D. R., Jr. \& SIMBERLOFF, D., 1981. Straining at gnats and swallowing ratios: character displacement. Evolution, 35: 810-812.

STRONG, D. R. Jr., SZYSKA, L. \& SIMBERLOFF, D., 1979. Tests of community-wide character displacement against null hypotheses. Evolution, 35: 897-913.

SULLOWAY, F. J., 1982a. The Beagle Collections of Darwin's Finches (Geospizinae). Bulletin of the British Museum (Natural History), Zoology series, 43: 49-94.

SUlLOWAY, F. J., 1982b. Darwin and his Finches: the evolution of a legend. Journal of the History of Biology, 15: $1-53$.

SWARTH, H. S., 1931. The avifauna of the Galápagos Islands. Occasional Papers of the California Academy of Sciences, 18: 1-299.

SWARTH, H. S., 1934. The bird fauna of the Galápagos Islands in relation to species formation. Biological Reviews, 9: 213-234.

TEMPLETON, A. R., 1981. Mechanisms of speciation-a population genetic approach. Annual Reviews of Ecology and Systematics, 12: 23-48.

THORPE, J. P., 1982. The molecular clock hypothesis: biochemical evolution, genetic differentiation and systematics. Annual Reviews of Ecology and Systematics, 13: 139-168.

YANG, S. H. \& PATTON, J. L., 1981. Genic variability and differentiation in Galápagos finches. Auk, 98: 230-242. 